\title{
The Effect of Temperature on the Salinity-Induced Changes in the Free Amino Acid Pool of Mya arenaria
}

\author{
William D. DuPaul \\ College of William and Mary - Virginia Institute of Marine Science
}

Follow this and additional works at: https://scholarworks.wm.edu/etd

Part of the Fresh Water Studies Commons, Marine Biology Commons, and the Oceanography Commons

\section{Recommended Citation}

DuPaul, William D., "The Effect of Temperature on the Salinity-Induced Changes in the Free Amino Acid Pool of Mya arenaria" (1968). Dissertations, Theses, and Masters Projects. Paper 1539617412.

https://dx.doi.org/doi:10.25773/v5-wp59-r937

This Thesis is brought to you for free and open access by the Theses, Dissertations, \& Master Projects at W\&M ScholarWorks. It has been accepted for inclusion in Dissertations, Theses, and Masters Projects by an authorized administrator of W\&M ScholarWorks. For more information, please contact scholarworks@wm.edu. 
THE EFFECT OF TEMPERATURE ON SALINITY-INDUCED CHANGES

IN THE FREE AMINO ACID POOL OF MYA ARENARIA

\author{
A Thesis \\ Presented to
}

The Faculty of the School of Marine Science

The College of William and Mary in Virginia

\author{
In Partial Fulfillment \\ Of the Requirements for the Degree of \\ Master of Arts
}

By

William D. DuPaul

1968 
APPROVAL SHEET

This thesis is submitted in partial fulfillment of the requirements for the degree of Master of Arts

\section{Author}

Approved, August 1968

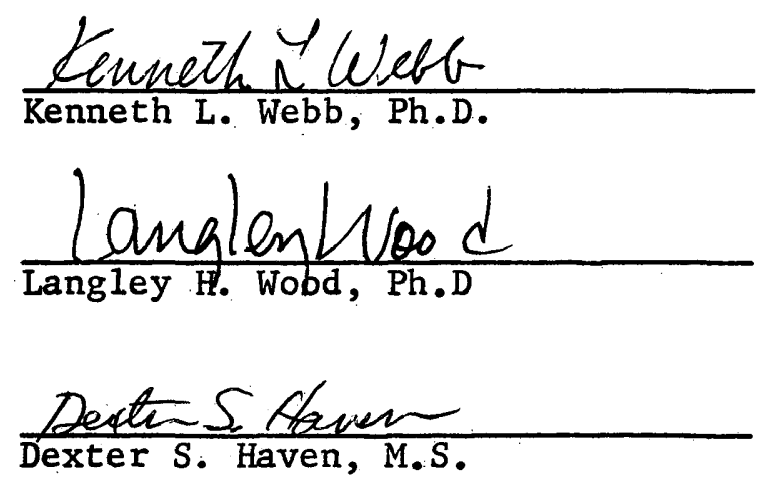




\section{ACKNOWLEDGEMENTS}

The author expresses appreciation to $\mathrm{Dr}$. Kenneth Webb for his support and advice that made this study possible. Additional thanks are extended to Dr. Langley Wood, Mr. Dexter Haven and Dr. Charlotte Mangum for their critical review of the manuscript. 
LIST OF FIGURES

Figure

Page

1. Accumulation of NPS ( $\mu \mathrm{M} / \mathrm{g}$ tissue water) in the anterior adductor muscle of warm acclimated $\mathrm{M}$. arenaria after a transfer from 20 to $30 \%$ sea. water..........................

2. Accumulation of NPS ( $\mu \mathrm{M} / \mathrm{g}$ tissue water) in the anterior adductor muscle of cold acclimated M. arenaria after a transfer from 20 to $30 \%$ sea water. . . . . . . . . . . . . . . . .

3. Accumulation of NPS ( $\mu \mathrm{M} / \mathrm{g}$ tissue water) in the anterior adductor muscle of $M$. arenaria after a transfer from 20 to $30 \%$ sea water. . . . . . . .

4. Accumulation of total FAA including unknown chromatogram peaks ( $\mu \mathrm{M} / \mathrm{g}$ tissue water) in the anterior adductor muscle of $\mathrm{M}$. arenaria after a transfer from 20 to $30 \%$ sea water.............

5. Accumulation of alanine ( $\mu \mathrm{M} / \mathrm{g}$ tissue wate $r$ ) in the anterior adductor muscle of $M$. arenaria after a transfer from 20 to $30 \%$ sea water. . . . . . .

6. Decrease of aspartic acid ( $\mu \mathrm{M} / \mathrm{g}$ tissue water) in the anterior adductor muscle of $M$. arenaria after a transfer from 20 to $30 \%$ sea water. . . . . .

7. Proposed multiple components in the accumulation of NPS and FAA in M. arenaria. . . . . . . . . .

8. Rate-temperature function of NPS accumulation for warm and cold acclimated $\mathrm{M}$. arenaria. . . . . . . . .

9. Rate-temperature of NPS accumulation for warm and cold acclimated $M$. arenaria over the entire time course of the experiment. . . . . . . . . . . 
TABLE OF CONTENTS

\section{Page}

ACKNOWLEDGEMENTS . . . . . . . . . . . . . . . iii

LIST OF TABLES . . . . . . . . . . . . . . . . v v

LIST OF FIGURES . . . . . . . . . . . . . . . . . vi vi

ABSTRACT . . . . . . . . . . . . . . . . . . vii

INTRODUCTION . . . . . . . . . . . . . . . . 2

METHODS AND MATERIALS . . . . . . . . . . . . . 4

Animals .................... 4

Tissue Preparation ................ 5

Ninhydrin Positive Substances (NPS) . . . . . . . 5

Individual Amino Acids . . . . . . . . . . 6

RESULTS . . . . . . . . . . . . . . . . . 7

DISCUSSION . . . . . . . . . . . . . . . . 23

SUMMARY . . . . . . . . . . . . . . . . 33

LITERATURE CITED . . . . . . . . . . . . . . 34 


\section{LIST OF TABLES}

Table

Page

I Summary of acclimation and experimental conditions. .

II NPS ( $\mu \mathrm{M} / \mathrm{g}$ tissue water) in the anterior adductor muscle of $M$. arenaria after transfer from 20 to $30 \%$ sea water.................

III Two and three way analysis of variance on NPS data. .

IV FAA ( $\mu \mathrm{M} / \mathrm{g}$ tissue water) in the anterior adductor muscle of M. arenaria before and after temperature acclimation .....................

$\mathrm{V}$ FAA ( $\mu \mathrm{M} / \mathrm{g}$ tissue water) in the anterior adductor muscle of $\underline{M}$. arenaria over the time course of the experiment....................... 


\begin{abstract}
Warm and cold acclimated $\underline{M}$. arenaria were transferred from sea water of $20 \%$ salinity to sea water of $30 \%$ salinity at 8,18 and $25 \mathrm{C}$. The observed accumulation of NPS was not linear in relation with time and a three component process in the accumulation of NPS is proposed. The time lag between two of the components produced a change in the rate of NPS accumulation around the 36 th hour. The increase in alanine concentration accounted for 80 to $90 \%$ of the observed NPS increase. The high correlation between the decrease in aspartic acid and the increase in alanine indicates a direct relationship in the formation of alanine from aspartic acid. The rate-temperature functions of NPS accumulation were not the type expected for warm and cold acclimated poikilotherms. The reverse translation pattern of the rate-temperature curves indicates that warm acclimated animals can accumulate NPS at a greater rate than the cold acclimated ones. The conclusion made from data obtained through the use of temperature as an environmental variable is consistent with the hypothesis that an enzyme system mediates the supply of amino acids for isosmotic intracellular regulation.
\end{abstract}


THE EFFECT OF TEMPERATURE ON SALINITY-INDUCED CHANGES

IN THE FREE AMINO ACID POOL OF MYA ARENARIA 


\section{INTRODUCTION}

The participation of small organic molecules in isosmotic intracellular regulation of many marine invertebrates was reviewed by Florkin and Schoffeniels (1965). They pointed out that, in marine invertebrates, the intracellular inorganic ion concentration is lower than the extracellular concentration and that the balance of osmotically active materials leading to an isosmotic concentration mainly consists of organic nitrogen compounds. A correlation between free amino acids (FAA) and ambient salinity consistent with the role of FAA in osmoregulation has been shown under laboratory conditions (Florkin and Schoffeniels, 1965). This correlation does not appear to be a laboratory artifact since high concentrations of total FAA in Crassostrea virginica correspond to high natural environmental salinities (Lynch and Wood, 1966). The source of FAA and the mechanism for their accumulation has been widely discussed. On the basis of work done on Eriocheir sinensis, Schoffeniels (1960) concluded that the osmotically active amino acids are of intracellular origin and that the environmental osmotic pressure per se is not responsible for the amino acid concentration; $\mathrm{Na}$ or $\mathrm{K}$ is necessary for the accumulation process. Possible sources of FAA are: (1) FAA are actively taken up from the external medium, (2) a greater percentage of FAA and nitrogenous material normally excreted or released is retained, (3) the FAA are obtained from the digestive tract and, (4) other FAA pools contribute to the FAA pool involved in isosmotic intracellular regulation. 
The effect of temperature on the FAA pool of marine animals is relatively unknown. Duchateau and Florkin (1955) reported for Eriocheir sinensis a decrease in proline at 2-3 Celsius (C) when compared to the same species kept at $10 \mathrm{C}$. More recently, Anders et al. (1962) found that a temperature change from $28 \mathrm{C}$ to $22 \mathrm{C}$ caused a rise in the level of tissue amino acids for the fish Platypoecilus and Xiphophorus. Rao (1963) found that the blood of the fresh water mussel, Lamellidens marginalis, showed an increase in total amino acids after warm acclimation (35 C) compared to cold acclimated (20 C) ones. Saroja and Rao (1965) reported that the body fluid FAA in the earthworm Lampito mauritii showed a decrease of $142.3 \%$ in warm acclimated animals (35 C) when compared to animals kept at normal conditions (28 C).

The purpose of this research was to determine the effect of temperature on the time course of the increase of FAA caused by an increase in salinity. The experiments are designed to permit characterization of the rate-temperature functions according to Precht (1958) and Prosser and Brown (1961). The determination of temperature effects on 18 identified amino acids found in Mya arenaria linne may also help elucidate the mechanism of accumulation of FAA in a more definitive manner. 


\section{METHODS AND MATERIALS}

\section{Animals}

Specimens of Mya arenaria were collected from a single intertidal mud-flat on the York.River (Virginia). At the time of collection (September 1967), water temperatures ranged from 20 to $23 \mathrm{C}$. One hundred and ninety animals were selected for size uniformity $(62 \pm 6 \mathrm{~mm})$ and kept in a laboratory table of running sea water with a salinity of $20.4 \pm 0.2 \%$ and a temperature of $21.0 \pm 1.0 \mathrm{C}$ for 8 days prior to temperature acclimation.

Two groups of animals were kept at $25 \mathrm{C}$ and $8 \mathrm{C}$ for 8 days and, in regard to their general metabolism, are referred to as warm and cold acclimated. Acclimation is virtually complete for most aquatic animals in a few days (Prosser and Brown, 1961, p. 242). Experiments consisted of placing warm and cold acclimated animals in glass battery jars containing $30 \%$ natural sea water at temperatures of 25,18 and $8 \mathrm{C}$. Samples were taken every 12 hours of the experiment for a duration of 60 to 84 hours. Other groups of $\underline{M}$. arenaria were kept at temperatures of 30,20 and $8 \mathrm{C}$ for various lengths of time. These groups supplied additional information and served as experimental controls. Table I summarizes the acclimation, experimental and control conditions.

Every 12 hours during the experiment, the animals were given a mixture of algae consisting of Monochrysis, Isochrysis and Phaeodactylum. Continuous aeration and daily changes of sea water prevented an excessive buildup of waste products. 


\section{Tissue Preparation}

Two portions of the anterior adductor muscle were dissected from M. arenaria. One portion, ca. $120 \mathrm{mg}$, was blotted, weighed, dried at $90 \mathrm{C}$ for 60 hours (to constant weight), and reweighed to determine the water content. The other portion ( $<100 \mathrm{mg})$ was blotted, weighed, and placed in 2 ml of $80 \%$ ethanol to extract the ninhydrin positive substances (Awapara, 1948). The per cent water content obtained for one portion of the adductor muscle was used to calculate water content and dry weight for the extracted tissue.

\section{Ninhydrin Positive Substances (NPS)}

NPS were determined from an aliquot $(0.1 \mathrm{ml})$ of the ethanol extract by the method described by Clark (1964). Each determination was done in duplicate. A standard of glycine was serially diluted $(0.01$ to $0.15 \mu \mathrm{M} / \mathrm{ml}$ ) and was analyzed with each group of tissue extracts. Colorimetric determinations were made at 570mu using a Bauch and Lomb Spectronic 20 colorimeter.

Values of NPS as glycine equivalents are expressed in $\mu \mathrm{M} / \mathrm{g}$ tissue water and statistical significance at the $95 \%$ level was determined by analysis of variance " $t$ " test and multiple range analysis (Snedecor, 1960). Values for NPS were computed using the mean per cent tissue water (75.2\%) of 36 animals from an environmental salinity of $20.4 \%$ and a temperature of $21.0 \mathrm{C}$. These were the conditions in the laboratory sea water tables prior to acclimation and establishment of experimental conditions. By using values corrected for changes in tissue water, changes in the concentration of NPS due to fluctuations in tissue water are eliminated. Thus values for NPS, unless otherwise stated, are net values corrected for water loss. Any change in value represents a real 
change in the concentration of NPS and is not affected by tissue water changes. This correction for water loss does not change the character of the NPS accumulation as a process, but only decreases the change in relative amounts and the variability between individual anima1s.

\section{Individual Amino Acids}

A qualitative and quantitative analysis of amino acids was made using an automatic ion exchange analyzer (Technicon Auto-Analyzer $R$ ). An aliquot $(0.1 \mathrm{~m} 1)$ of the ethanol extract was mixed with $0.2 \mathrm{ml} 0.1 \mathrm{~N}$ $\mathrm{HCl}$ and 0.25 uM L-amino guanido propionic acid was added as an internal standard. This mixture was dried, then redissolved with $2.0 \mathrm{ml} 0.1 \mathrm{~N}$ HC1 and 0.25 uM Norleucine added to serve as a second internal standard; samples were then lyophylized. The samples were redissolved in $0.1 \mathrm{~N}$ $\mathrm{HCl}$ and injected under $\mathrm{N}_{2}$ pressure into a $0.6 \mathrm{~cm} \times 129 \mathrm{~cm}$ heated $(60 \mathrm{C})$ glass column filled with Technicon Chromobeads B ${ }^{2}$. A gradient of sodium citrate buffers ( $\mathrm{pH} 2.875$ to 5.000 ) with a flow rate of $0.5 \mathrm{ml} / \mathrm{min}$ served as an eluent.

The color developed with ninhydrin was determined at 440 and $570 \mathrm{mu}$ through $15-\mathrm{mm}$ light path continuous flow cuvettes. Amino acids were identified by comparing unknown peaks with those of a known 21 amino acid standard solution (General Biochemicals, Chagrin Falls, Ohio).

As with the NPS, all amino acid values are calculated on the basis of $75.2 \%$ tissue water and are corrected for loss of tissue water. 


\section{RESULTS}

After temperature acclimation, the warm acclimated animals showed a significant change in tissue water with a mean value of $73.3 \%$ as compared to $75.2 \%$ in unacclimated animals. Cold acclimated animals showed no significant change in tissue water content. The loss of tissue water under experimental conditions did not account for all the increase in NPS concentration but was responsible for $4-11 \%$ of the change.

There were no significant differences in NPS among warm, cold and unacclimated animals with or without correction for tissue water change. Total NPS values for $19 \underline{\text { M. }}$ arenaria before temperature acclimation ranged from 232.6 to $353.3 \mu \mathrm{M} / \mathrm{g}$ tissue water. NPS for cold acclimated animals ranged from 286.0 to $344.6 \mu \mathrm{M} / \mathrm{g}$ tissue water and for warm acclimated animals, 294.5 to $320.2 \mu \mathrm{M} / \mathrm{g}$ tissue water. Values for warm and cold acclimated animals were pooled to obtain a common baseline for a comparison to conditions of increased salinity.

NPS values obtained at both acclimation conditions and conditions of increased salinity are summarized in Table II. There were definite increases in NPS concentration over the time course of the experiment. Figures 1 and 2 show an initial increase of NPS concentration which reached a peak at 12 or 24 hours depending upon experimental conditions; the greater the temperature change, the sooner this peak was reached. With the exception of cold acclimated animals at $8 \mathrm{C}$, a significant drop in NPS concentration occurred at 36 , hours only to be followed by 
a second increase. This second increase was also influenced by temperature but, unlike the initial increase, higher levels and a greater rate of NPS accumulation occurred with warmer temperatures regardless of acclimation temperature. This latter pattern of response remains essentially the same for three groups of animals each acclimated to a different experimental temperature (Fig. 3).

The results of two- and three-way analysis of variance for the NPS values obtained at various experimental conditions are presented in Table III. The warm and cold acclimated groups and the group of animals acclimated to each experimental temperature showed significant differences in NPS concentration for time, temperature and for interaction between time and temperature. In the analysis in which only the warm and cold acclimated groups were combined, significant differences in NPS concentration remained for time, temperature and for interaction between time and temperature. Significant differences at the $5 \%$ level between adjacent times and temperatures were tested by use of multiple range analysis. The results of these tests are included in Table II.

The 18 identified amino acids in $\underline{M}$. arenaria accounted for 69 to $95 \%$ of the measured NPS. In Table IV, the quantities of the 18 FAA are presented for acclimated and unacclimated conditions. Glycine and alanine made up the greatest part of the FAA pool and constituted 70 to $76 \%$ of the total. Other FAA in order of decreasing concentrations were taurine, glutamic acid, arginine, aspartic acid and serine, each contributed 1 to $9 \%$ of the total.

There were no statistical differences in the total of the 18 identified amino acids when the warm and cold acclimated groups were compared with the unacclimated group. However, there were statistical differences in the total of the 18 amino acids between the warm and cold 
acclimated animals. In addition to the 18 identified FAA, the chromatogram showed other peaks that are, at this time, unidentified. Values ranged from 7.99 to $24.86 \mathrm{\mu M} / \mathrm{g}$ tissue water (norleucine equivalents). These unidentified materials constituted about $5 \%$ of the measured NPS. There were no statistical differences between the three groups of animals when the combined totals of the unknown and known amino acids were considered.

Because of the large variability in the concentration of individual FAA, no significant differences were detected when the unacclimated animals were compared to the warm and cold acclimated animals. However, there were significant differences in two important FAA between warm and cold acclimated animals. In the warm acclimated group the mean values of taurine and glycine were lower than in the cold acclimated group by 12.05 and $27.30 \mathrm{\mu M} / \mathrm{g}$ tissue water respectively. Although the majority of the values presented in Table $V$ are from only one chromatogram, some idea as to the variability of each FAA is obtained at time zero for warm and cold acclimated animals (Table IV). Also, the values for warm acclimated animals at $18 \mathrm{C}$ (36 hours) represent the mean and standard deviation for three individuals (Table V).

FAA totals showed definite changes over the time course of the experiment (Table V) and the pattern of accumulation was similar to that of the NPS accumulation.

of the individual FAA, glycine and alanine were the most concentrated at experimental conditions. Alanine made up 33.7 to $59.8 \%$ of the FAA pool while glycine made up 22.2 to $48.9 \%$ of the pool. The response of glycine to an increase in salinity was variable. There was a slight increase in the concentration of glycine but, its mole percentage of 
the FAA pool decreased over the time course of the experiment. Data for glycine is presented in Table $\mathrm{V}$.

Over the time course of the experiments, the mole \% of alanine in the FAA pool increased for warm and cold acclimated animals. The mole \% of alanine in the FAA pool was significantly different for both groups of animals at each of the three experimental temperatures; by the end of the experiment, higher experimental temperatures resulted in higher percentages of alanine in the FAA pool. For the warm acclimated animals between 12 and 36 hours of the experiment, there was an inversion in the quantities of alanine in relation to temperature and the curves demonstrated a change in slope (Fig. 5a). This is similar to the behavior pattern of the total FAA and NPS in relation to time and temperature (Fig. 1, 4a). The alanine in the cold acclimated animals presented a somewhat similar response to experimental conditions. The alanine content of the animals at $18 \mathrm{C}$ demonstrated a pronounced two-step increase in concentration whereas at 8 and $25 \mathrm{C}$ there appeared to be a simple increase and no noticeable change in the slope of the curve (Fig. 5b). Other amino acids such as taurine, glutamic acid and arginine. each made up $2 \%$ or more of the FAA pool. The data for these amino acids are presented in Table V. There was a slight but noticeable increase in the quantities. of serine and phenylalanine during experimental conditions. The concentration of serine approximately doubled from its baseline value with values as high as $6.51 \mu \mathrm{M} / \mathrm{g}$ tissue water but, it seldom was responsible for more than $2 \%$ of the FAA pool. The increase in phenylalanine was less pronounced and more erratic than that of serine and was consistently less than $2 \%$ of the FAA pool. 
The remaining FAA, cysteic acid, methionine sulfoxide, proline, valine, isoleucine, leucine, tryptophane, ornithine, lysine, histidine and threonine showed little if any change at experimental conditions and each contributed less than $2 \%$ of the FAA pool. The only amino acid that consistently decreased in concentration with time during the experiments was aspartic acid. Initial values ranged from $17.38 \pm 3.65(3)$ to $11.87 \pm 4.39(3) \mathrm{uM} / \mathrm{g}$ tissue water for warm and cold acclimated animals respectively. These values dropped to between 1.10 and 5.52 $\mu \mathrm{M} / \mathrm{g}$ tissue water depending upon experimental conditions. Data for aspartic acid is presented in Table V and Fig. 6a, b. 
Table I. Summary of acclimation and experimental conditions. 


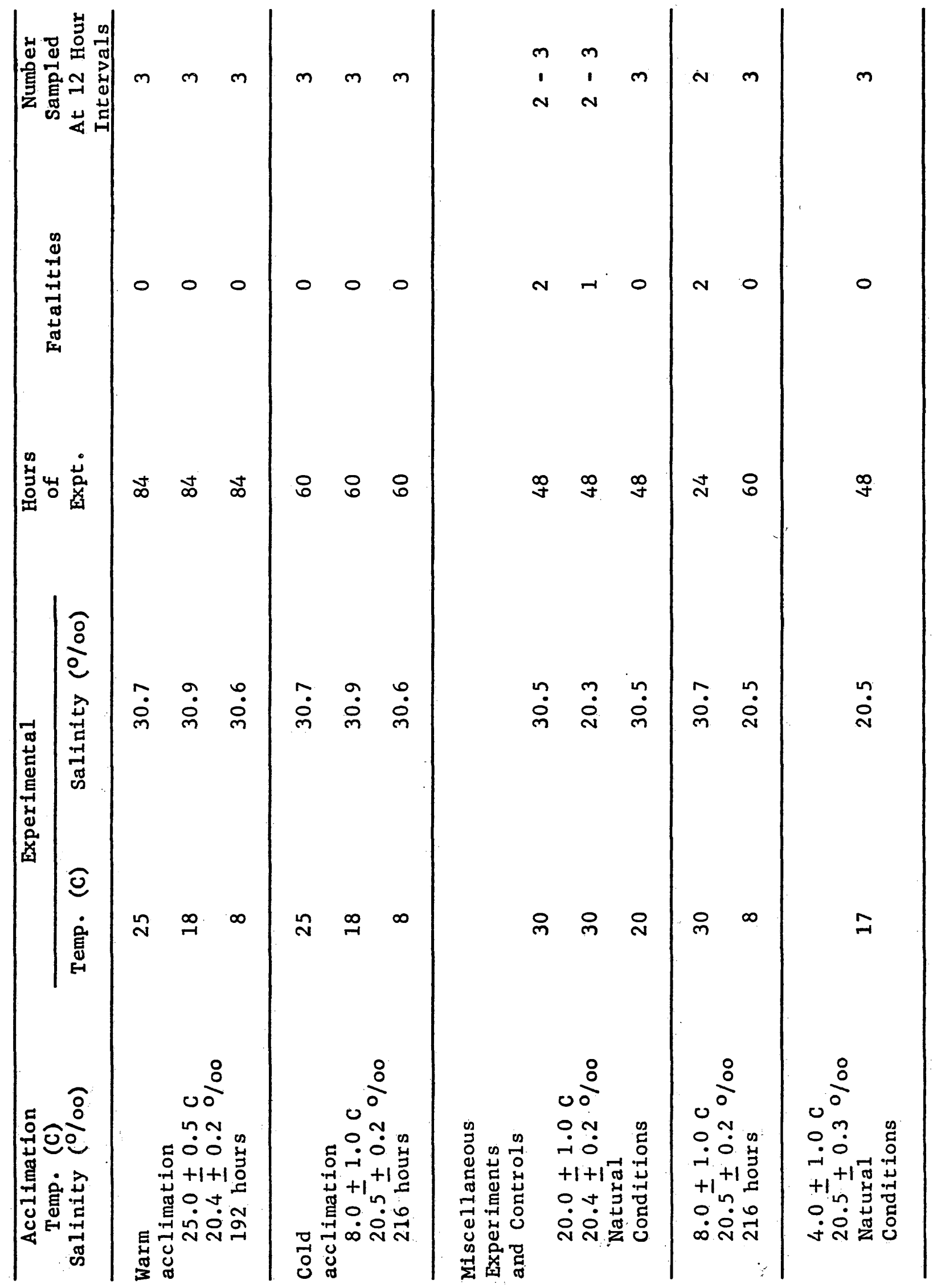


Table II. NPS ( $\mu \mathrm{M} / \mathrm{g}$ tissue water) in the anterior adductor muscle of M. arenaria after transfer from 20 to $30 \%$ water. Values are the mean and SD for three animals except for time zero where $\mathrm{N}=19$.

(I) No significant differences at the $95 \%$ level from previous time values.

(II) No significant differences at the $95 \%$ level between experimental temperatures. 


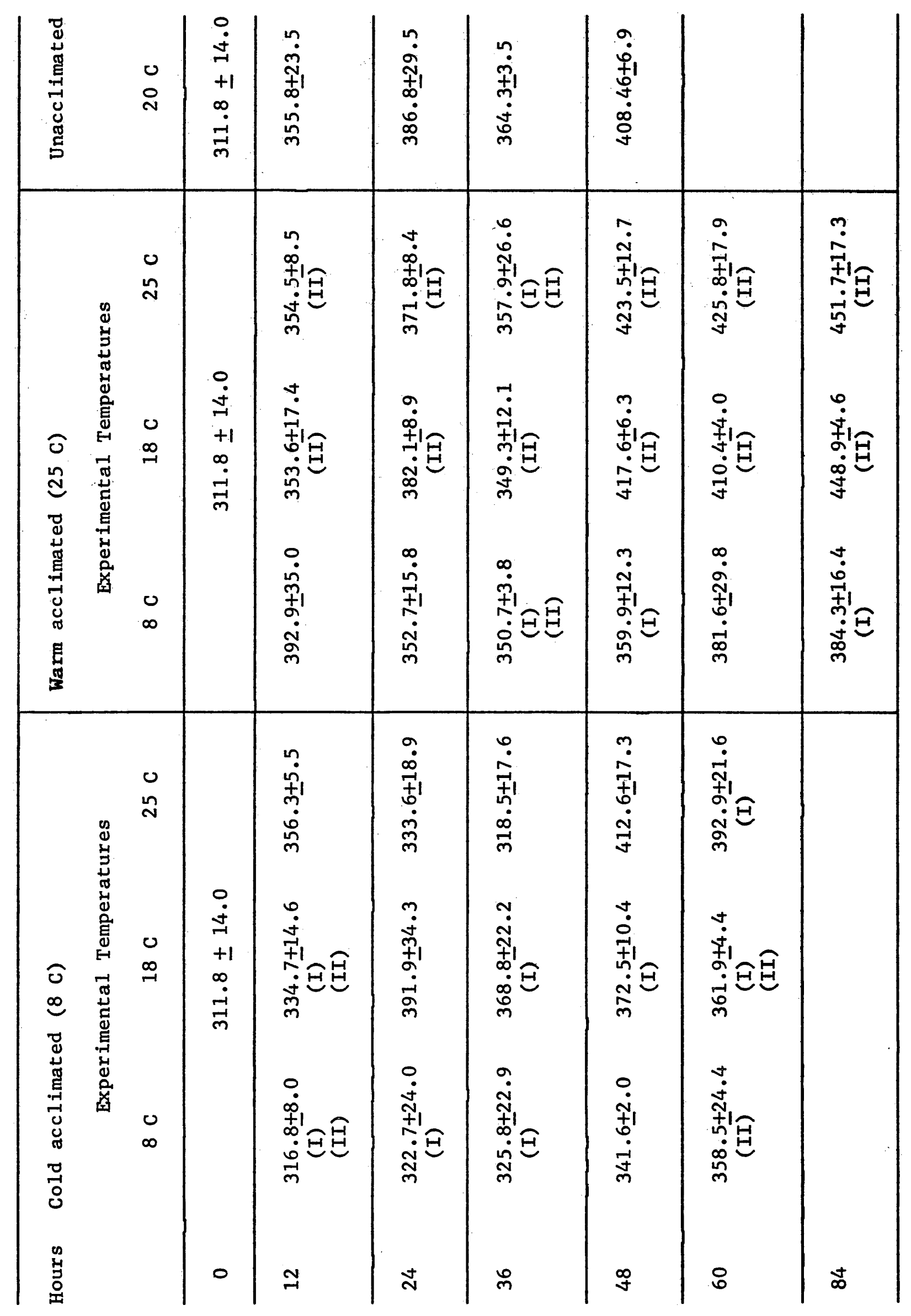


Table III. Two- and three-way analysis of variance on NPS data. 


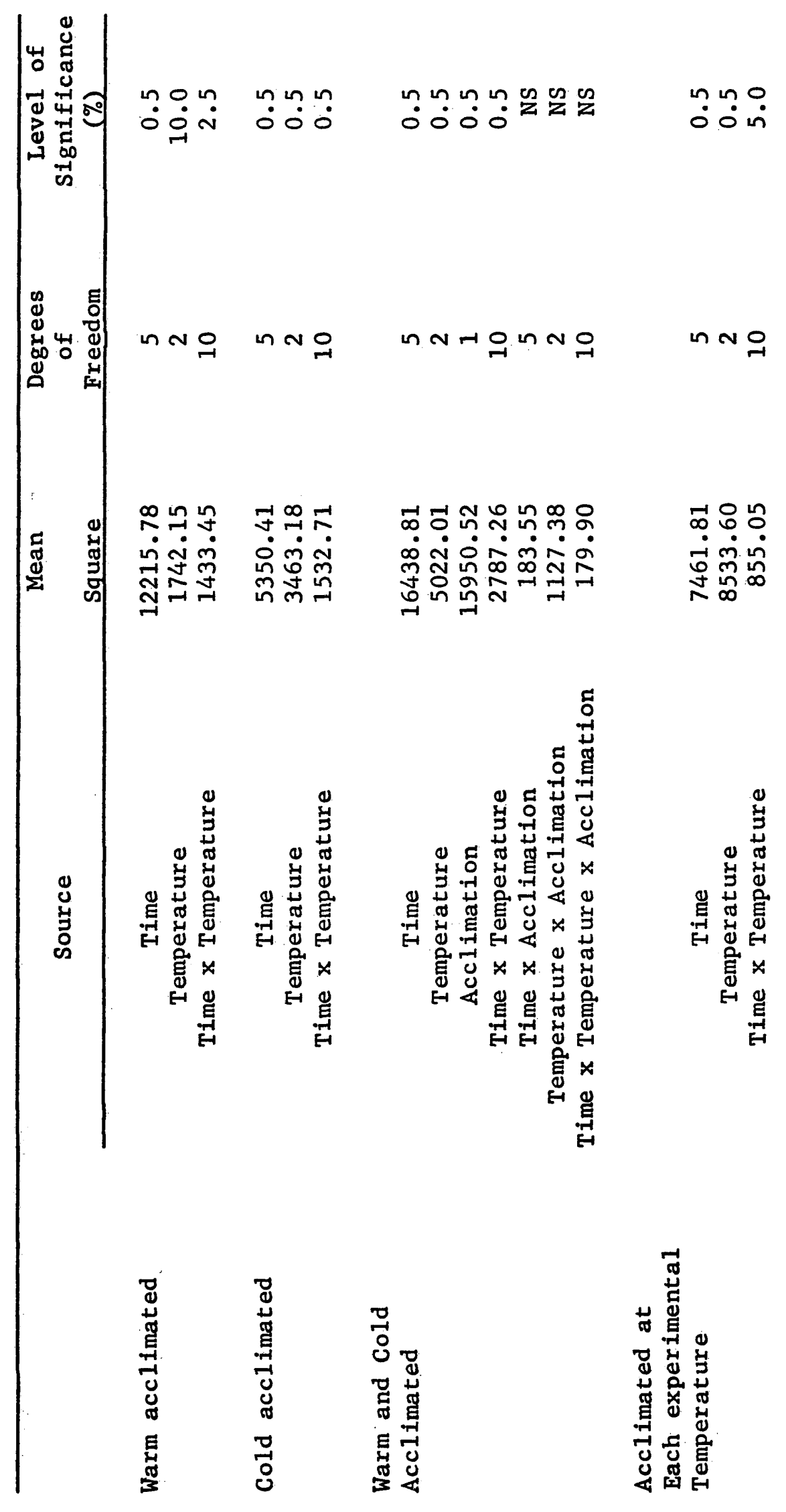


Table IV. FAA ( $\mu \mathrm{M} / \mathrm{g}$ tissue water) in the anterior adductor muscle of M. arenaria before and after temperature acclimation. Each value represents mean and SD. 


\begin{tabular}{|c|c|c|c|c|c|c|}
\hline \multirow{2}{*}{$\begin{array}{c}\text { Pree amino } \\
\text { acid }\end{array}$} & \multicolumn{2}{|c|}{ Before acclimation } & \multicolumn{2}{|c|}{$\begin{array}{l}\text { Warm acclimation } \\
25 \mathrm{C}\end{array}$} & \multicolumn{2}{|c|}{$\begin{array}{l}\text { Cold acclimation } \\
8 \mathrm{C}\end{array}$} \\
\hline & $N=8$ & Mole $\%$ & $N=3$ & Mole $\%$ & $\mathrm{~N}=3$ & Mole $\%$ \\
\hline Cyateic acid & $1.62 \pm 0.57$ & 0.66 & $2.04 \pm 0.74$ & 0.90 & $1.40 \pm 0.20$ & 0.56 \\
\hline Taurine & $16.05+4.76$ & 6.59 & $11.05 \pm 5.62$ & 4.86 & $23.10 \pm 3.59$ & 9.31 \\
\hline $\begin{array}{l}\text { Methionine } \\
\text { sulfoxide }\end{array}$ & $0.38 \pm 0.23$ & 0.15 & $0.74 \pm 0.20$ & 0.33 & $0.26 *$ & 0.10 \\
\hline Appartic acid & $11.77 \pm 4.90$ & 4.88 & $17.38+3.65$ & 7.66 & $11.88+4.38$ & 4.78 \\
\hline Threonine & $2.41 \pm 0.88$ & 0.98 & $3.93 \pm 0.90$ & 1.73 & $1.91 \pm 0.06$ & 0.77 \\
\hline Serine & $2.95 \pm 1.19$ & 1.21 & $1.86 \pm 0.66$ & 0.82 & $2.51 \pm 0.66$ & 1.01 \\
\hline Glutamic acid & $14.59+2.46$ & 6.13 & $13.91 \pm 1.44$ & 6.12 & $13.90 \pm 1.92$ & 5.61 \\
\hline Glycine & $86.00 \pm 22.61$ & 35.31 & $73.68 \pm 9.70$ & 32.43 & $100.98 \pm 1.46$ & 40.70 \\
\hline Alanine & $90.58 \pm 14.04$ & 37.19 & $85.03 \pm 11.90$ & 37.43 & $85.81 \pm 19.01$ & 34.59 \\
\hline Valine & $0.56 \pm 0.31$ & 0.23 & $0.85 \pm 0.32$ & 0.37 & $0.49 *$ & 0.19 \\
\hline Isoleucine & $0.42 \pm 0.25$ & 0.17 & $0.54 \pm 0.25$ & 0.24 & $0.28 *$ & 0.11 \\
\hline Leucine & $0.59 \pm 0.34$ & 0.24 & $0.68 \pm 0.13$ & 0.30 & $0.45 \pm 0.21$ & 0.18 \\
\hline Tyrosine & $0.43 \pm 0.36$ & 0.17 & $0.72 \pm 0.13$ & 0.32 & $.0 .30 *$ & 0.12 \\
\hline Phenylalanine & $2.08 \pm 0.73$ & 0.85 & $2.21 \pm 0.56$ & 0.97 & $1.55 \pm 0.37$ & 0.62 \\
\hline Ornithine & $1.44 \pm 1.30$ & 0.59 & $0.97 \pm 0.16$ & 0.43 & $0.40 *$ & 0.16 \\
\hline Lysine & $1.51 \pm 0.77$ & 0.62 & $1.97 \pm 0.35$ & 0.87 & $1.31 \pm 0.81$ & 0.52 \\
\hline Tryptophan & $1.34 \pm 0.85$ & 0.55 & $1.25 \pm 0.46$ & 0.55 & $0.50 *$ & 0.20 \\
\hline Histidine & $0.45 \div 0.19$ & 0.18 & $0.25 \pm 0.12$ & 0.11 & $0.20 *$ & 0.08 \\
\hline Arginine & $9.01 \pm 2.19$ & 3.28 & $8.47 \pm 0.71$ & 3.73 & $7.52 \pm 0.63$ & 3.03 \\
\hline $\begin{array}{l}\text { Total } \\
2 \text { of NPS }\end{array}$ & $\begin{array}{c}247.99 \pm 39.35 \\
85.45 \pm 7.61\end{array}$ & & $\begin{array}{r}227.16 \pm 3.41 \\
73.63 \pm 1.51\end{array}$ & & $\begin{array}{c}248.06 \pm 17.20 \\
86.07 \pm 5.67\end{array}$ & \\
\hline $\begin{array}{l}\text { Total plus } \\
\text { unidentified } \\
\text { peaks } t \\
z \text { of NPS }\end{array}$ & $\begin{array}{c}261.51 \pm 35.85 \\
90.49 \pm 8.12\end{array}$ & & $\begin{array}{r}242.49 \pm 3.65 \\
79.70 \pm 3.75\end{array}$ & & $\begin{array}{c}254.40 \pm 18.05 \\
90.03 \pm 8.06\end{array}$ & \\
\hline
\end{tabular}


Table V. FAA ( $\mu \mathrm{M} / \mathrm{g}$ tissue water) in the anterior adductor muscle of $\underline{M}$. arenaria over the time course of the experiment. Values where $N=3$ are the mean and $S D$; where $N=2$, values are the mean of two animals. 


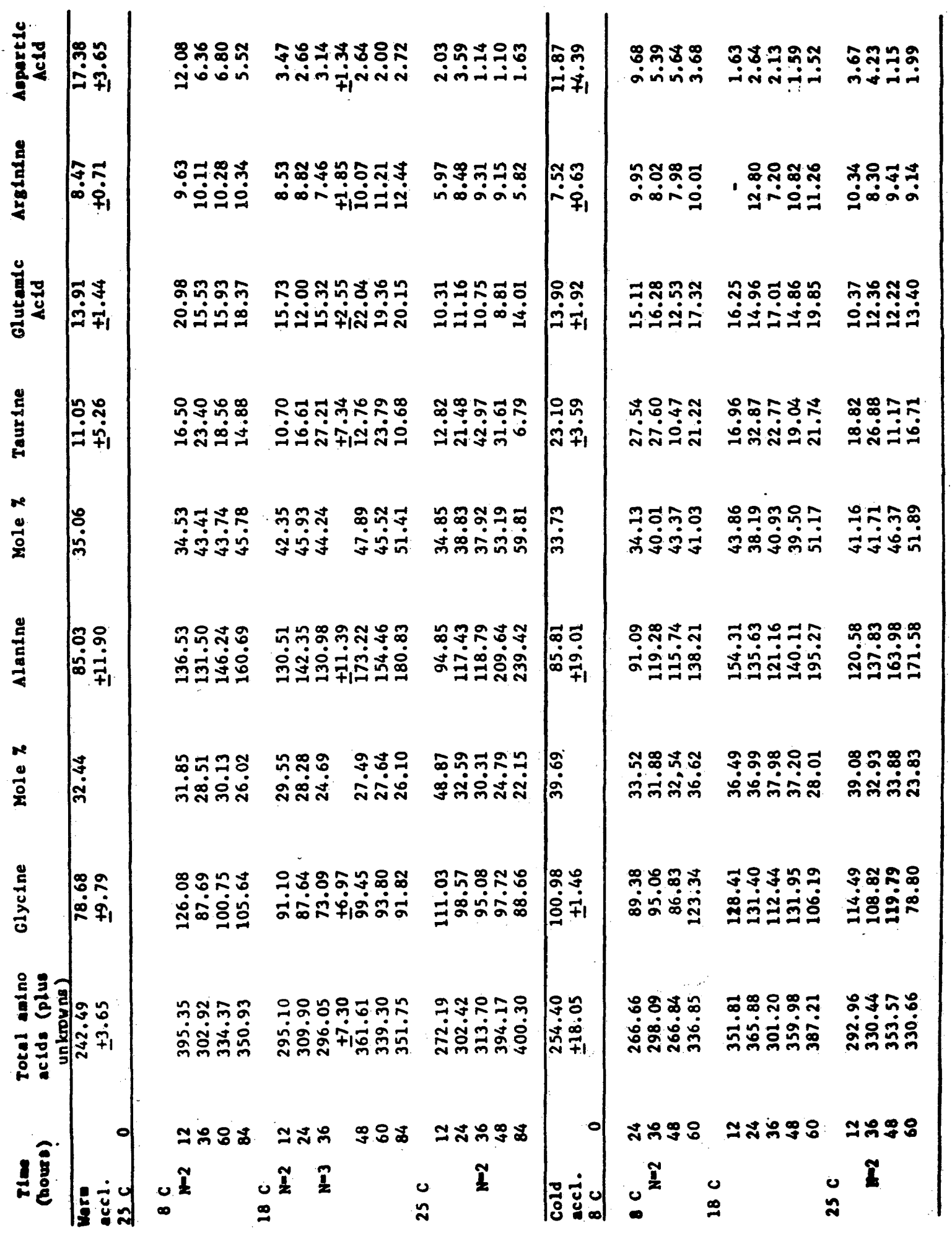


Figure 1. Accumulation of NPS ( $\mu \mathrm{M} / \mathrm{g}$ tissue water) in the anterior

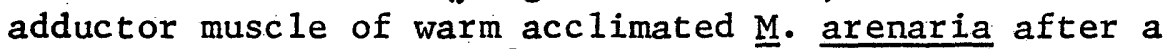
transfer from 20 to $30 \%$ sea water. 


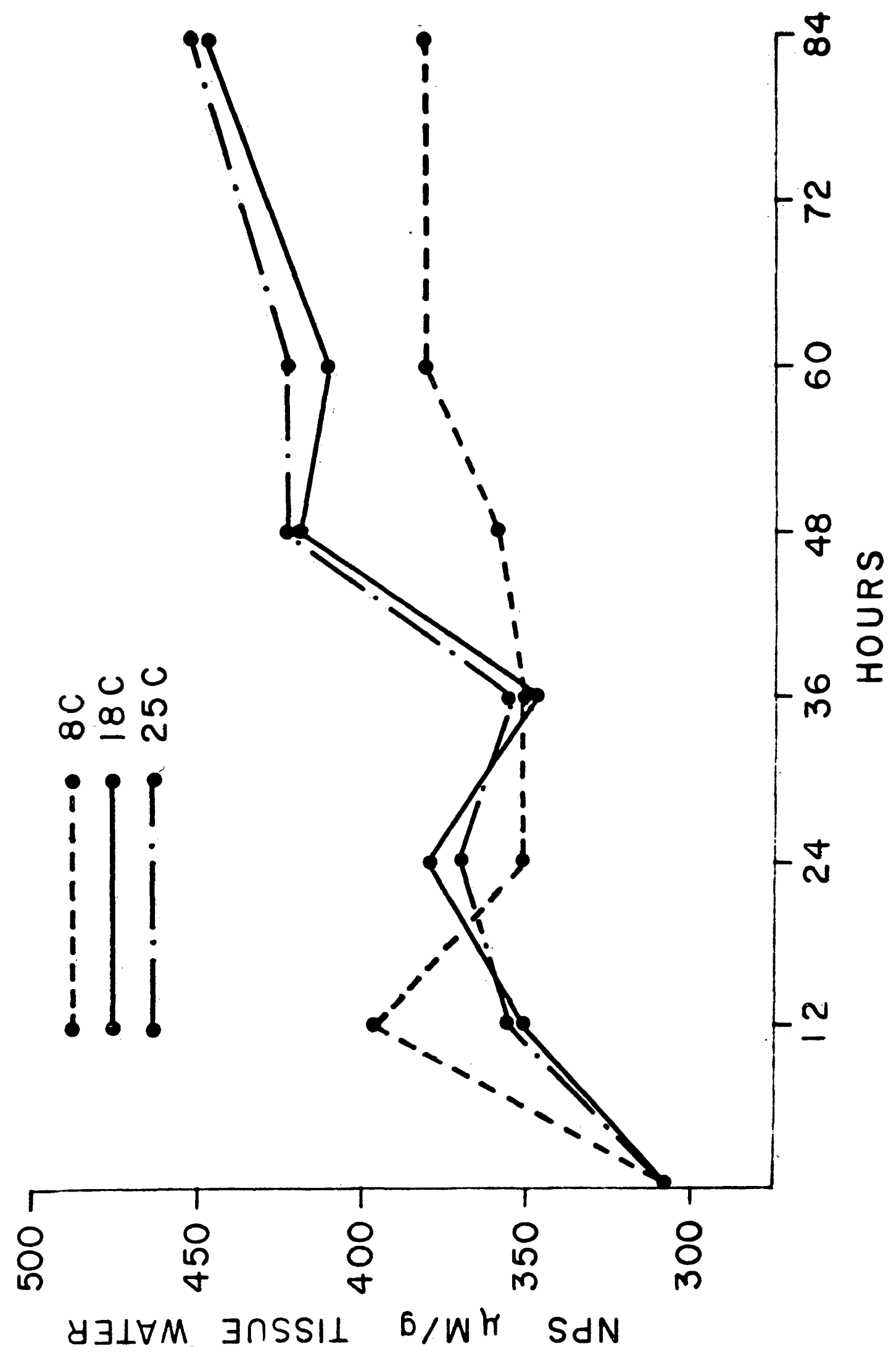


Figure 2. Accumulation of NPS ( $\mu \mathrm{M} / \mathrm{g}$ tissue water) in the anterior adductor muscle of cold acclimated $\underline{\text { M. arenaria after a }}$ transfer from 20 to $30 \%$ sea water. 


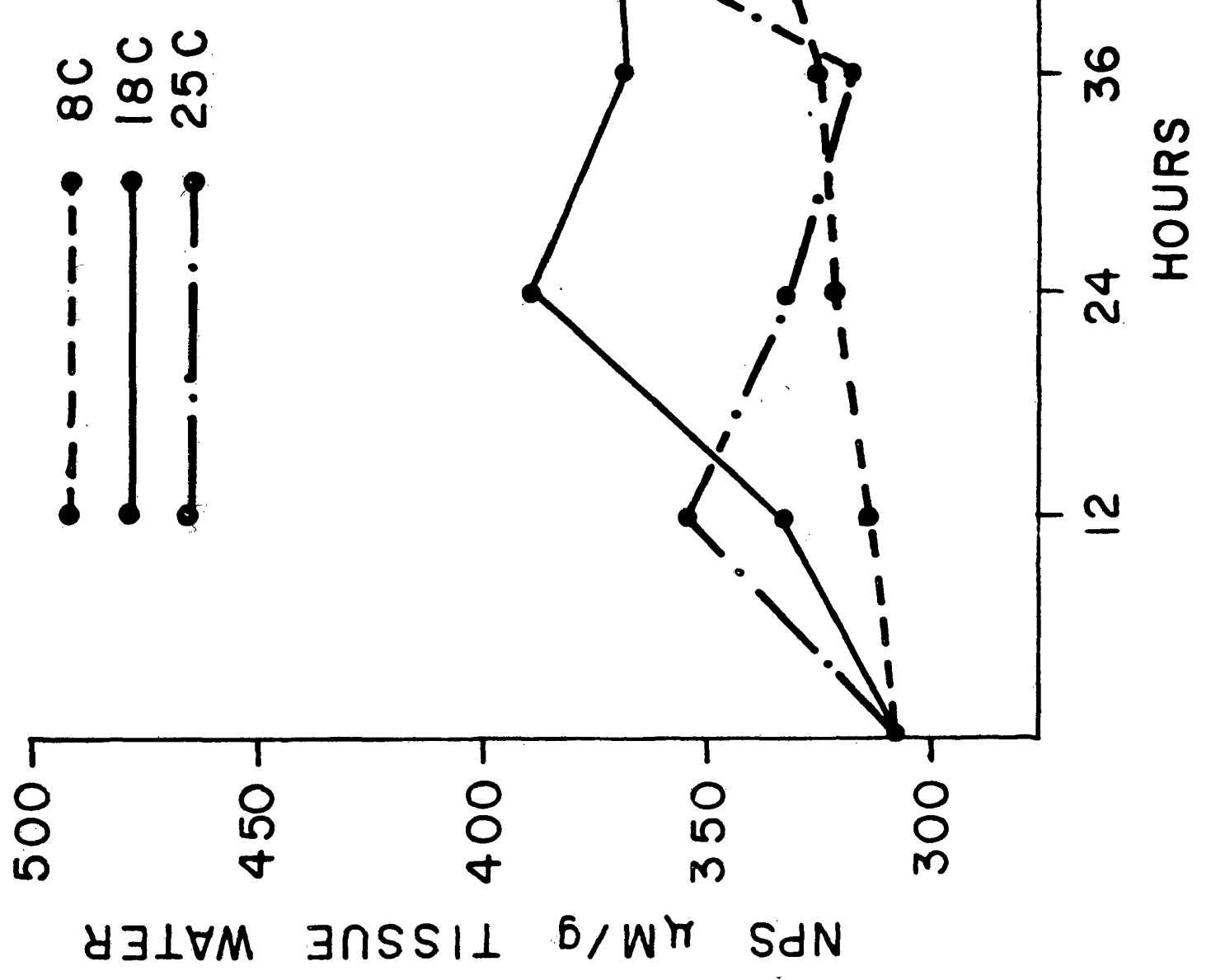


Figure 3. Accumulation of NPS (uM/g tissue water in the anterior adductor muscle of $\mathrm{M}$. arenaria after a transfer from 20 to $30 \%$ sea water. Each group of animals was acclimated to each experimental temperature. 


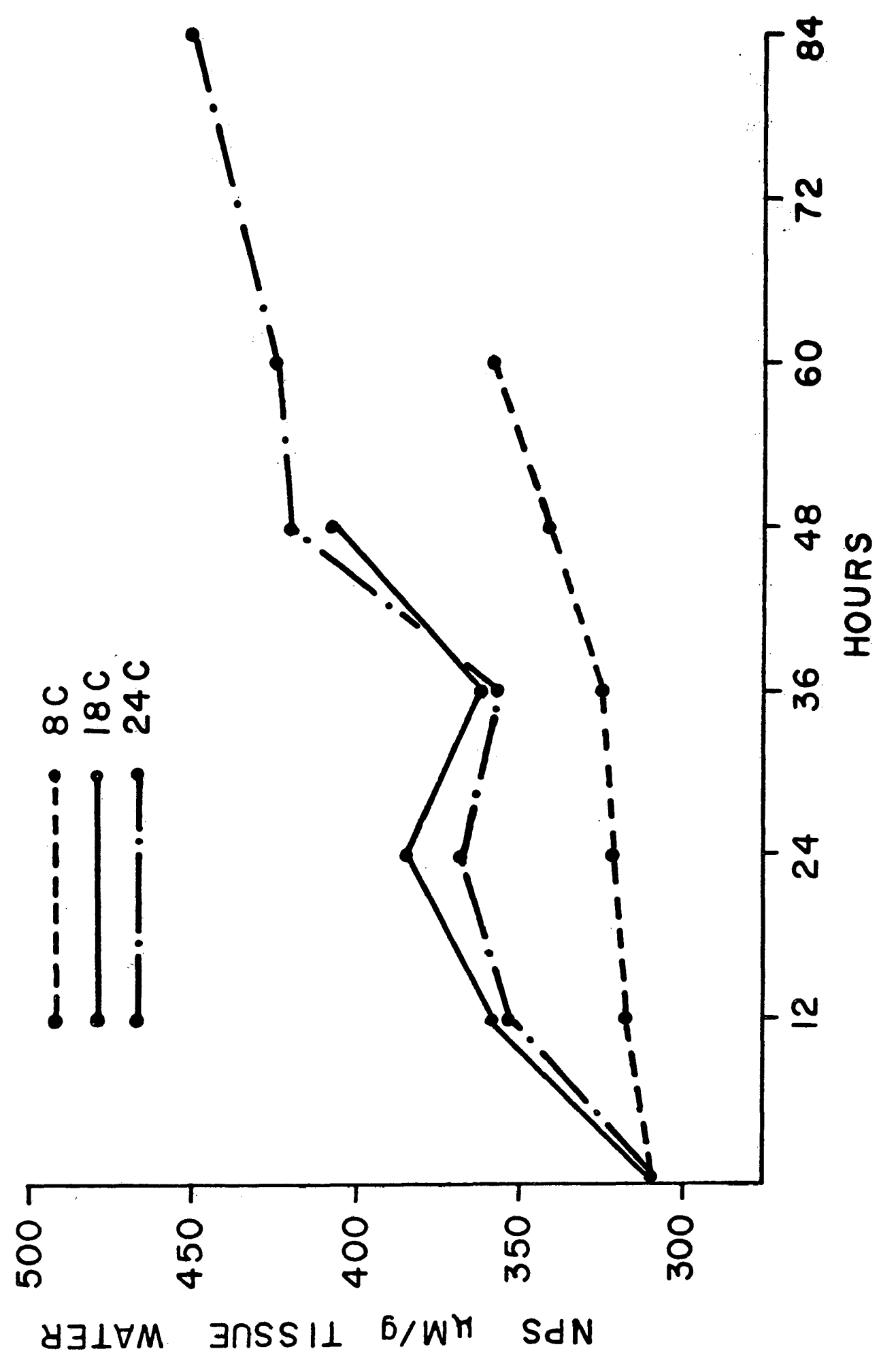


Figure 4. Accumulation of total FAA including unknown chromatogram peaks ( $\mu \mathrm{M} / \mathrm{g}$ tissue water) in the anterior adductor muscle of $\underline{M}$. arenaria after a transfer from 20 to $30 \%$ sea water.

A. Cold acclimated.

B. Warm acclimated. 


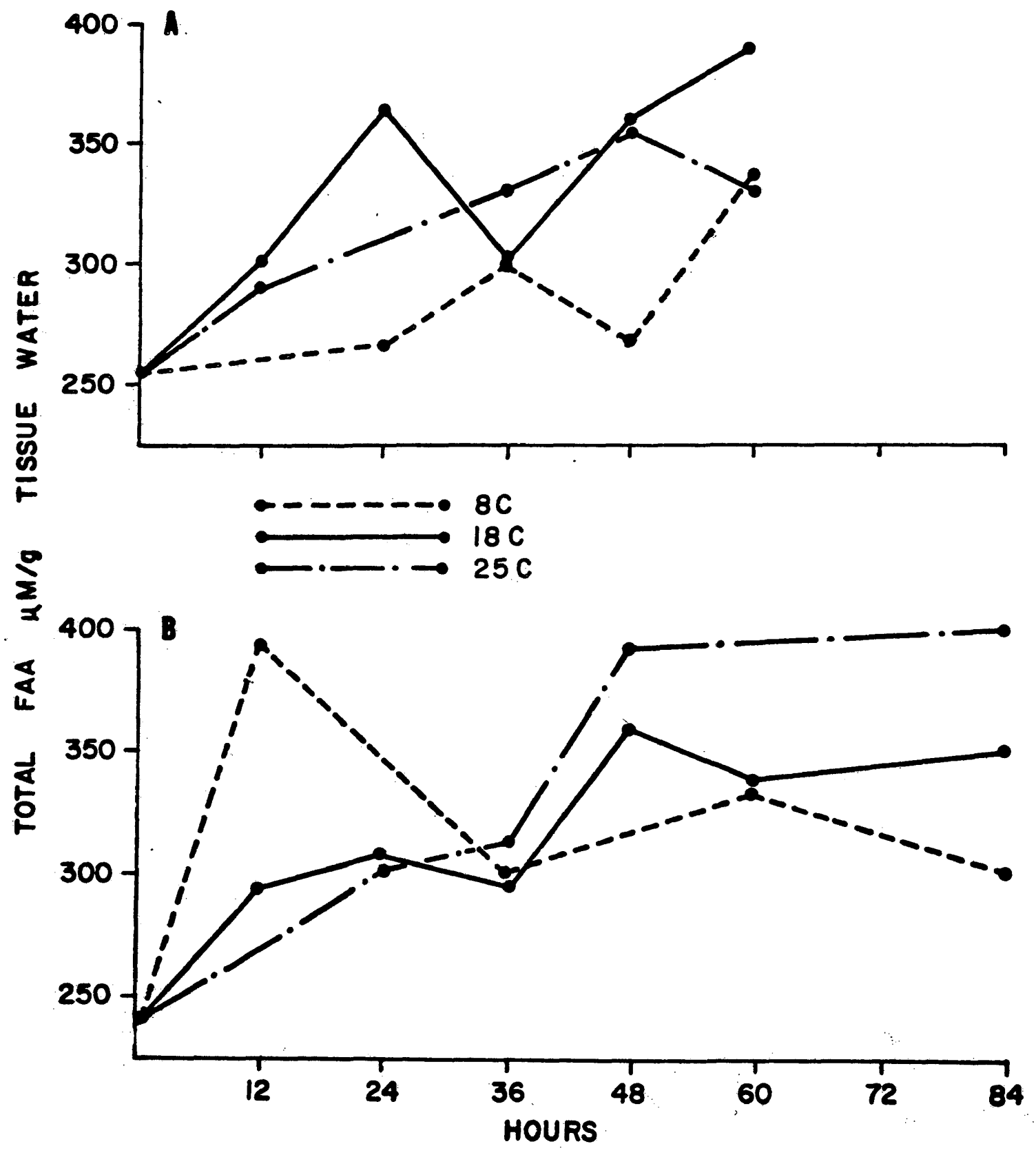


Figure 5. Accumulation of alanine ( $\mu \mathrm{M} / \mathrm{g}$ tissue water) in the anterior adductor muscle of $\underline{M}$. arenaria after a transfer from 20 to $30 \%$ sea water.

A. Warm acclimated.

B. Cold acclimated. 

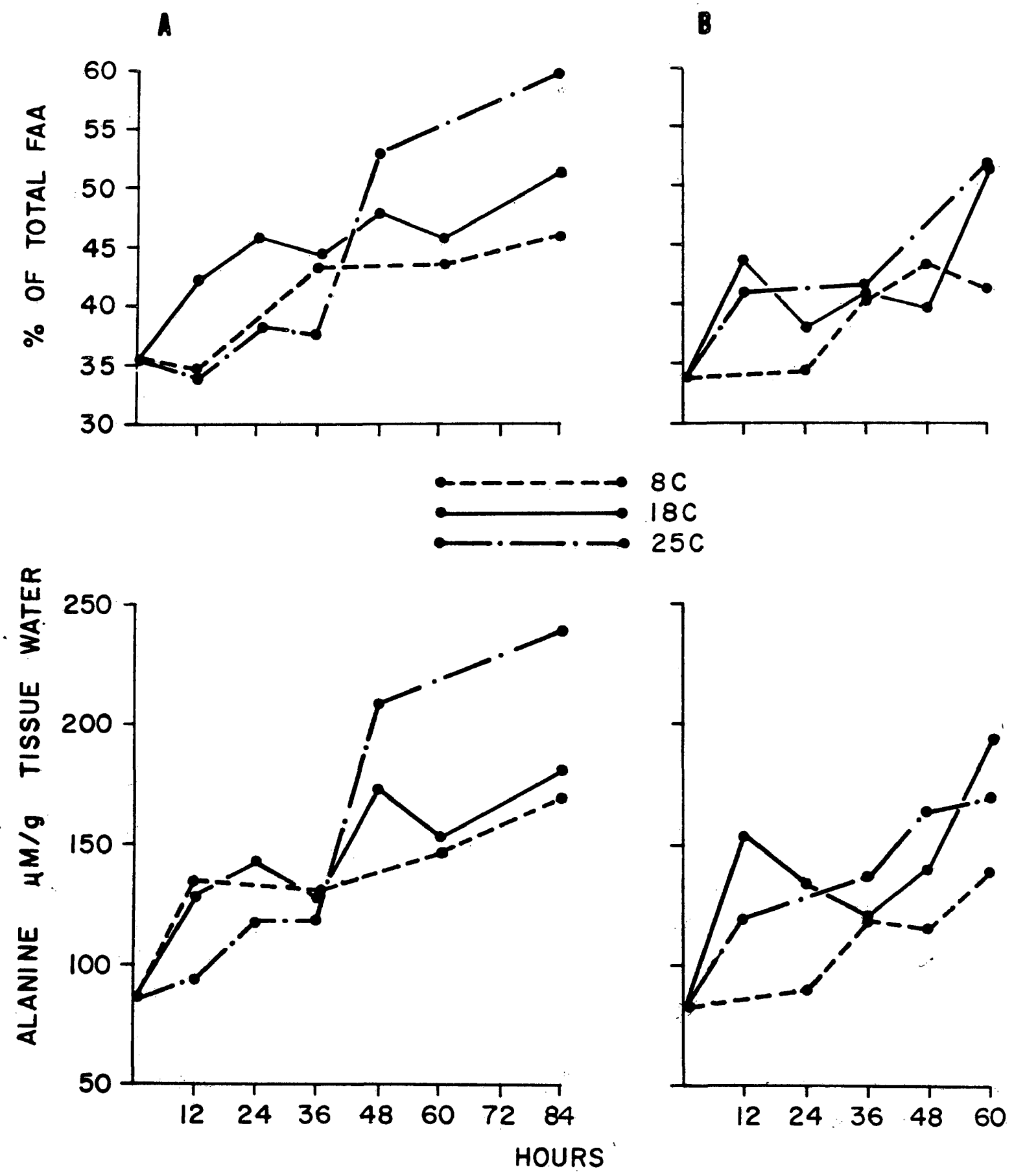
Figure 6. Decrease of aspartic acid ( $\mu \mathrm{M} / \mathrm{g}$ tissue water) in the anterior adductor muscle of $\underline{\mathrm{M}}$. arenaria after a transfer from 20 to $30 \%$ sea water.

A. Warm acclimated.

B. Cold acclimated. 

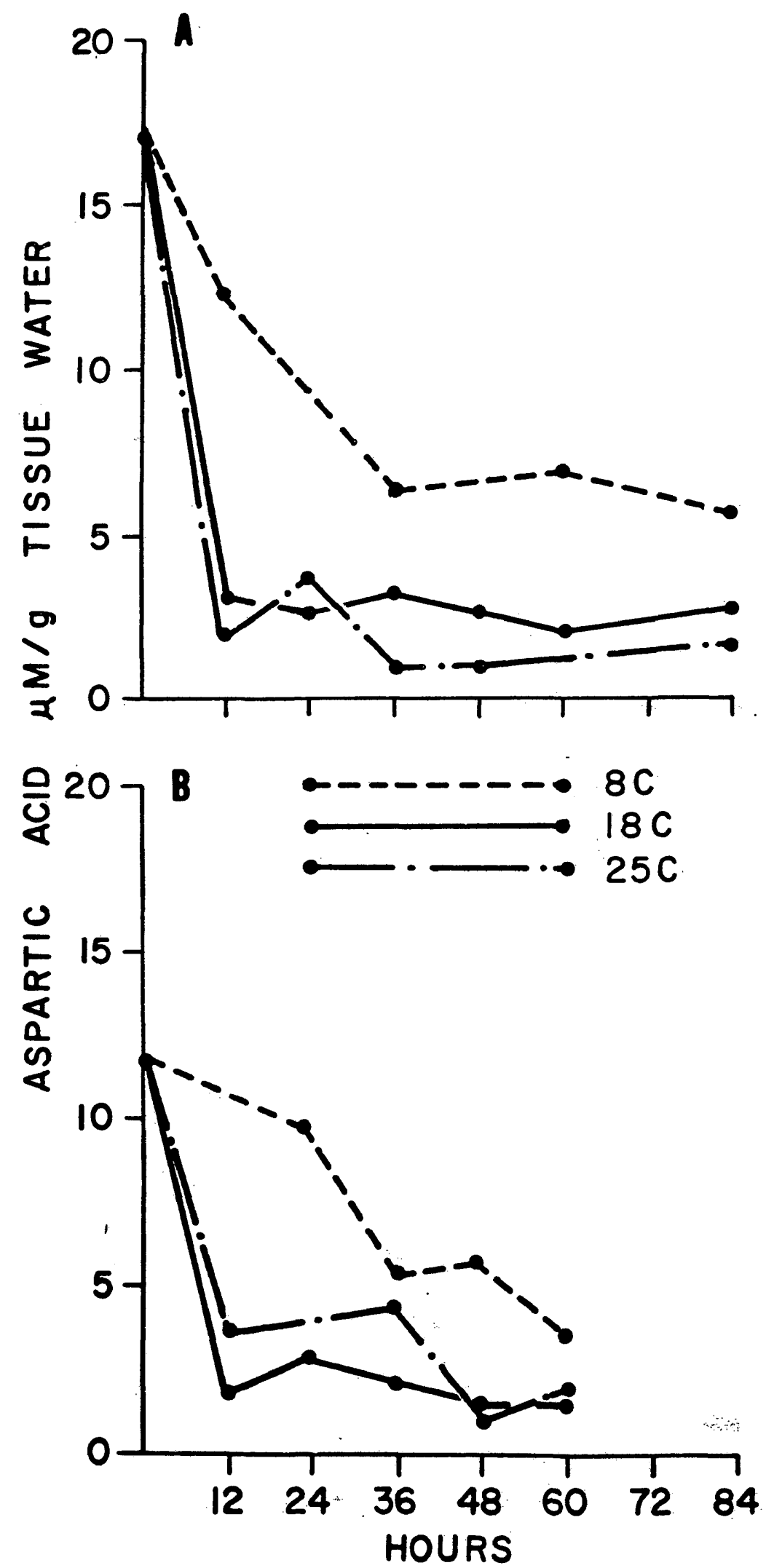
DISCUSSION

Several authors have demonstrated that there is a linear relationship between salinity and NPS or total FAA in muscle tissue of the marine pelecypods Mytilus edulis (Lange, 1963), Crassostrea virginica (Lynch and Wood, 1966) and Mya arenaria (Virkar and Webb, unpublished data). M. arenaria accumulates NPS and total FAA in response to a salinity increase in a fashion that is not linear with time. Except for cold acclimated animals at $25 \mathrm{C}$, the accumulation of NPS and total FAA changed in rate or significantly decreased in absolute concentration around the 36th hour (Figs. 1, 2, 3 and 4). The exception for cold acclimated animals at $25 \mathrm{C}$ may be an artifact of the 12 hour sampling interval. The patterns of NPS and total FAA accumulation indicate that there may be multiple steps involved in this process. The slight transitory increase in the glycine concentration during the first 24 hours of experimental conditions along with a more pronounced increase in the concentration of alanine accounted for more than $80 \%$ of the NPS increase. Also, the slight transitory increase of the FAA pool as a whole during the first 12 to 24 hours contributed to the observed initial increase in NPS concentration. The change in the rate of NPS increase that occurred around the 36 th hour was caused either by the decrease or lack of increase in the concentration of alanine. After 36 hours, the concentration of alanine increased sharply and accounted for approximately $90 \%$ of the NPS increase. The interpretation of multiple steps in NPS accumulation 
is valid as shown by the significant interaction between time and temperature in the analysis of variance (Table III) and multiple range analysis (Table II).

From the above analysis, it is apparent that there may be at least two major processes involved in the accumulation of NPS; a "fast component" that operates during the first 24 hours after a salinity. increase and a "slow component" that obtains its effective rate after 36 hours. Since M. arenaria is an osmoconformer (Hegemann, 1964), the fast component may be useful in preventing excessive tissue water loss and cell volume changes. Data on adductor muscle tissue water indicate that no further significant water loss occurs after 24 to 36 hours of exposure to an increase of salinity. This is consistent with the idea that the active adjustment of the intracellular osmotic pressure to new osmotic pressure could prevent a change in hydration of the cells. (Jeuniaux, Bricteux-Gregoire and Florkin, 1961) and effect cell volume regulation (Lange, 1968).

There was a transitory increase in the concentration of taurine around the 36 th hour of experimental conditions which coincided with the general decrease of the other osmotically active substances. Since the initial concentration of taurine was lower in warm acclimated animals than in cold acclimated ones, the increase was more noticeable in the warm acclimated group. This is interpreted as another indication of the presence of multiple components in the accumulation process of osmotically active substances. The increase was not large (7-20 $\mathrm{m} / \mathrm{g}$ tissue water) and appeared to be acting in response to the decrease or lack of increase in the concentration of alanine at the time when the proposed fast and slow components are in a transition stage. 
Three proposed components to account for the observed accumulation of FAA in $\underline{M}$ arenaria are presented in Fig. 7. The proposed fast component (A) may be partly from the release of osmotically active FAA from an osmotically inactive form. During the first 36 hours of the experiment, this supply of osmotically inactive amino acids is exhausted. This, combined with the continual loss or leakage of FAA from the osmotically active pool, produces a net loss or decrease in the concentration of FAA in the cell around the 36 th hour. At approximately the same time, the long ranged slow component (B) begins to supply FAA faster than they are lost as noted by the sharp net increase in the concentration of alanine. The time lag between these two components produces the change in slope in the accumulation of osmotically active FAA (D). The initial peak and subsequent decrease in the concentration of FAA is not interpreted as an overshoot phenomenon because the 12 to 24 hour concentration is considerably lower than the final concentration. A third component (C) is the transitory increase in the concentration of taurine at about 36 hours. Without this increase, the drop in total osmotically active FAA

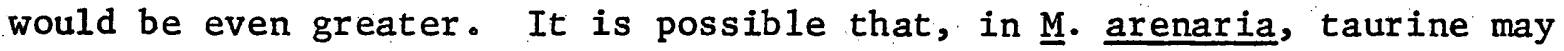
be used as an auxiliary and become an important osmotically active substance when other FAA are not available in sufficient quantities to accomplish isosmotic intracellular regulation. In contrast, taurine has a major role in the isosmotic intracellular regulation at increased salinities in Mytilus edulis (Lange, 1963) and Crassostrea virginica (Lynch and Wood, 1966). Lange (1963) reported that Mytilus edulis establishes its high concentration of NPS primarily by an increase in taurine and in this regard, exerts a sparing action on the animals use of "essential" amino acids. This may also be true for Crassostrea virginica, as Lynch and Wood (1966) showed that taurine is the most concentrated amino acid 
above a salinity of $19 \%$ and there the concentration of glycine, alanine and glutamic acid remains relatively constant.

On the basis of experiments performed on isolated nerves of Eriocheir sinensis it was concluded that the amino acids contributing to the total osmotic pressure are of intracellular origin (Schoffeniels, 1960). Gilles and Schoffeniels (1966) identified an aspartate decarboxylase in the ventral nerve chain of Homarus vulgaris. They concluded that L-alanine synthesis depends on at least two major pathways: (a) a transamination of pyruvate and (b) a decarboxylation of aspartate. The decarboxylation of aspartic acid to alanine has also been reported for microorganisms (Mahler and Cordes, 1966). The decarboxylation of aspartic acid could be an important pathway in the supply of alanine as an osmotically active substance in the muscle tissue of $\underline{M}$. arenaria. At all experimental temperatures there was a close relationship between the decrease of aspartic acid and the increase in the concentration of alanine. The correlation coefficients for the relationship between aspartic acid and alanine concentrations in five of six experiments range from $r=-0.74$ to $\mathbf{r}=-0.98$. In the sixth experiment with warm acclimated animals at $25 \mathrm{C}$, the correlation disappears as the concentration of alanine exceeds $200 \mu \mathrm{M} / \mathrm{g}$ tissue water and the aspartic acid appears to have a lower limit of $1.10 \mu \mathrm{M} / \mathrm{g}$ tissue water. Nevertheless, the correlation indicates a direct pathway in the formation of alanine from aspartic acid. The fact that the decrease of aspartic acid is less at $8 \mathrm{C}$ than at 18 and $25 \mathrm{C}$ (Fig. $6 \mathrm{a}, \mathrm{b}$ ) is an indication that the conversion of aspartic acid to alanine is temperature sensitive. These data are in agreement with the general hypothesis presented by Schoffeniels (1967) that the increased intracellular content of osmotically active amino acids 
after a transfer to a hypertonic medium is ascribed partly to a decrease in the breakdown or loss and partly to the increase in the synthesis of amino acids.

The rate-temperature function for NPS accumulation during the first 24 hours of experimental conditions (fast component) does not follow the standard patterns for warm and cold acclimated poikilotherms as described by Prosser and Brown (1962) and Precht (1958). When the warm and cold acclimated $\underline{M}$. arenaria experienced a temperature change, the rate of NPS accumulation increased regardless of the direction of the temperature change (Fig. 8a). The data for alanine indicate that the amino acid follows the pattern of accumulation similar to that of the NPS. The reason for the rate-temperature inversion is unknown at this time, but it may be the result of the additional stress caused by the sudden temperature change.

Intertidal populations of $\underline{M}$. arenaria in an area subject to fresh water runoff could be exposed to simultaneous salinity and temperature fluctuations. The fast component of NPS accumulation may serve as a response to both a temperature and salinity stress but it must be kept in mind that, in the range tested, temperature alone does not elicit this response. Unpublished data on experimental control animals show a slight but significant increase in NPS only when the temperature reaches $30 \mathrm{C}$; the changes occur around the $48 \mathrm{th}$ hour of control conditions. The concentration and composition of the NPS pool remains relatively stable within the temperature and time limits of these experiments ( 8 to $25 \mathrm{C}$ for approximately 10 days).

The rate-temperature functions of NPS accumulation in Figure $8 \mathrm{~b}$ were constructed from data between time zero and 60 hours. The resulting 
pattern of reverse translation (e.g. the curve of the cold acclimated animals lies to the right and below that of warm acclimated ones) may be the result of other factors complicating the response (Prosser and Brown, 1962). This is the case for the rate-temperature functions of NPS accumulation as it was affected by two changed parameters, temperature and salinity. The combined effect of each environmental condition presents rate-temperature functions which do not correspond to the normal patterns for poikilotherms (Prosser and Brown, 1962) and subsequent interpretations may not be applicable. An arithmetic plot of NPS accumulation is presented in Figure 9. The optimum temperature range for NPS accumulation is different for warm and cold acclimated animals. Warm acclimated animals had a greater accumulation rate at 18 and $25 \mathrm{C}$ than at $8 \mathrm{C}$. The accumulation rates at 18 and $25 \mathrm{C}$ were not appreciably different. The rate of NPS accumulation for cold acclimated animals was greatest at $25 \mathrm{C}$ and was different from the rate at $18 \mathrm{C}$. There were no appreciable differences in the accumulation rates between 8 and $18 \mathrm{C}$. It would appear that temperatures above 25 C are optimum for NPS accumulation in cold acclimated animals but preliminary studies indicate that under these experimental conditions higher temperatures have lethal effects on the animals.

The effect of temperature on the rate of NPS accumulation, which is the type expected for an enzyme mediated pathway within certain temperature limits, is another indication that the supply of amino acids for isosmotic intracellular regulation in $\underline{\text { M. }}$ arenaria is controlled by an enzyme system. This is in agreement with a statement by Lange (1968) that the size of the FAA pool in the cell is at least partly controlled by the activity of amino acid synthesizing enzymes. The reason why the warm acclimated animals have a faster rate of NPS accumulation than cold 
acclimated ones at the same temperature is unknown at this time. One reason may be that the amino acid synthesizing enzymes have to be manufactured to meet the demand of isosmotic intracellular regulation. If this is so, the warm acclimated animals having a more active metabolism would probably be able to manufacture the enzymes needed faster than the cold acclimated animals.

In conclusion, data obtained through the use of temperature as an environmental variable is consistent with the hypothesis that an enzyme system mediates the synthesis of amino acids for isosmotic intracellular regulation. The indications that alanine is synthesized from aspartic acid in the muscle tissue of $\underline{M}$. arenaria imply that the major osmotically active amino acid, alanine, is neither obtained by active uptake from the environment nor supplied completely from sources of osmotically inactive amino acids. However, these possibilities as well as others must be considered as a source of osmotically active amino acids especially for other marine invertebrates. 
Figure 7. Proposed multiple components in the accumulation of NPS and FAA in $\underline{\text { M. arenaria. }}$

A. Fast component.

B. Slow component.

C. Taurine component.

D. Composite of multiple component process. 

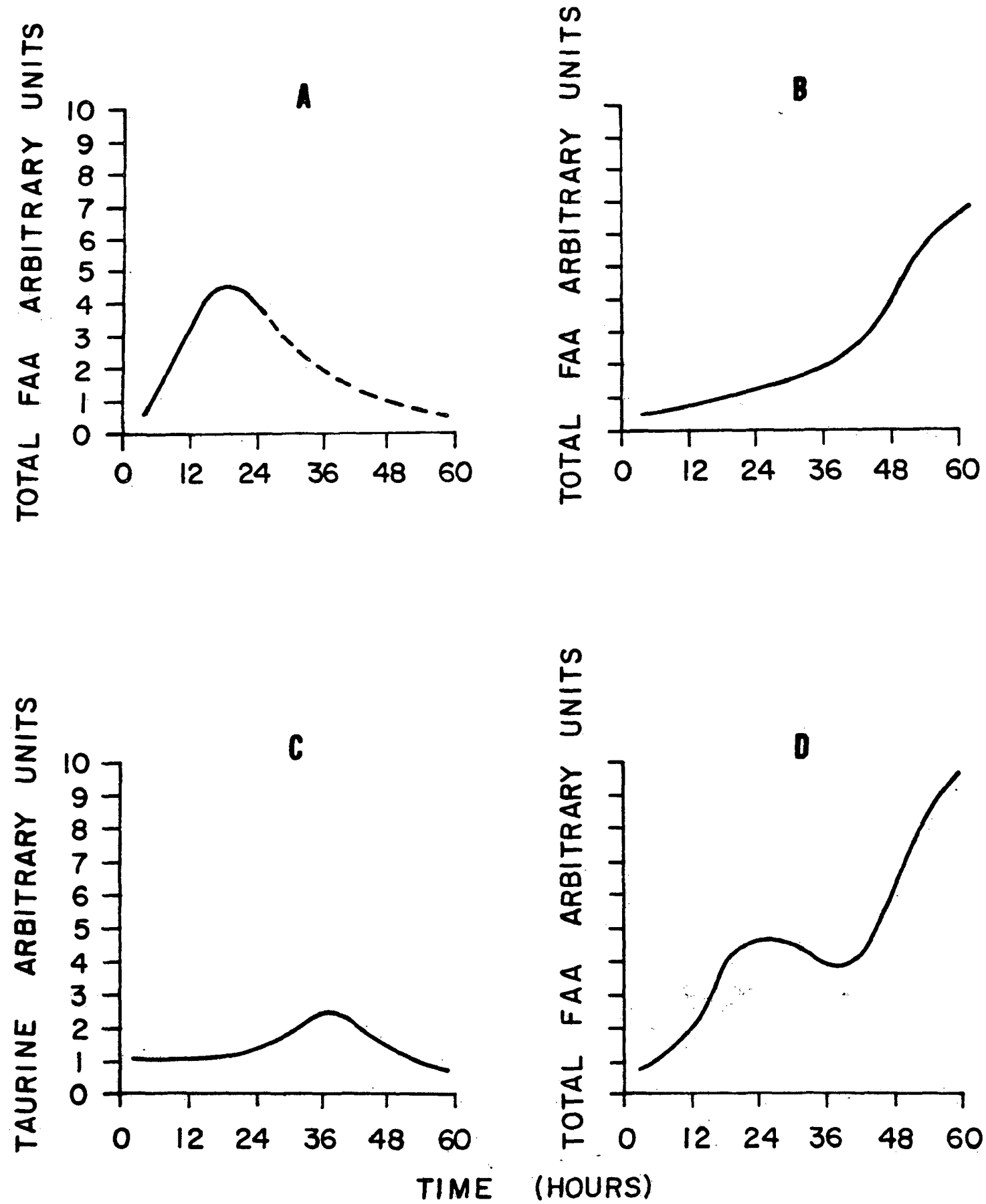
Figure 8. Rate-temperature function of NPS accumulation for warm and cold acclimated $M$. arenaria.

A. Initial increase (fast component).

B. Accumulation over entire time course of the experiment. 


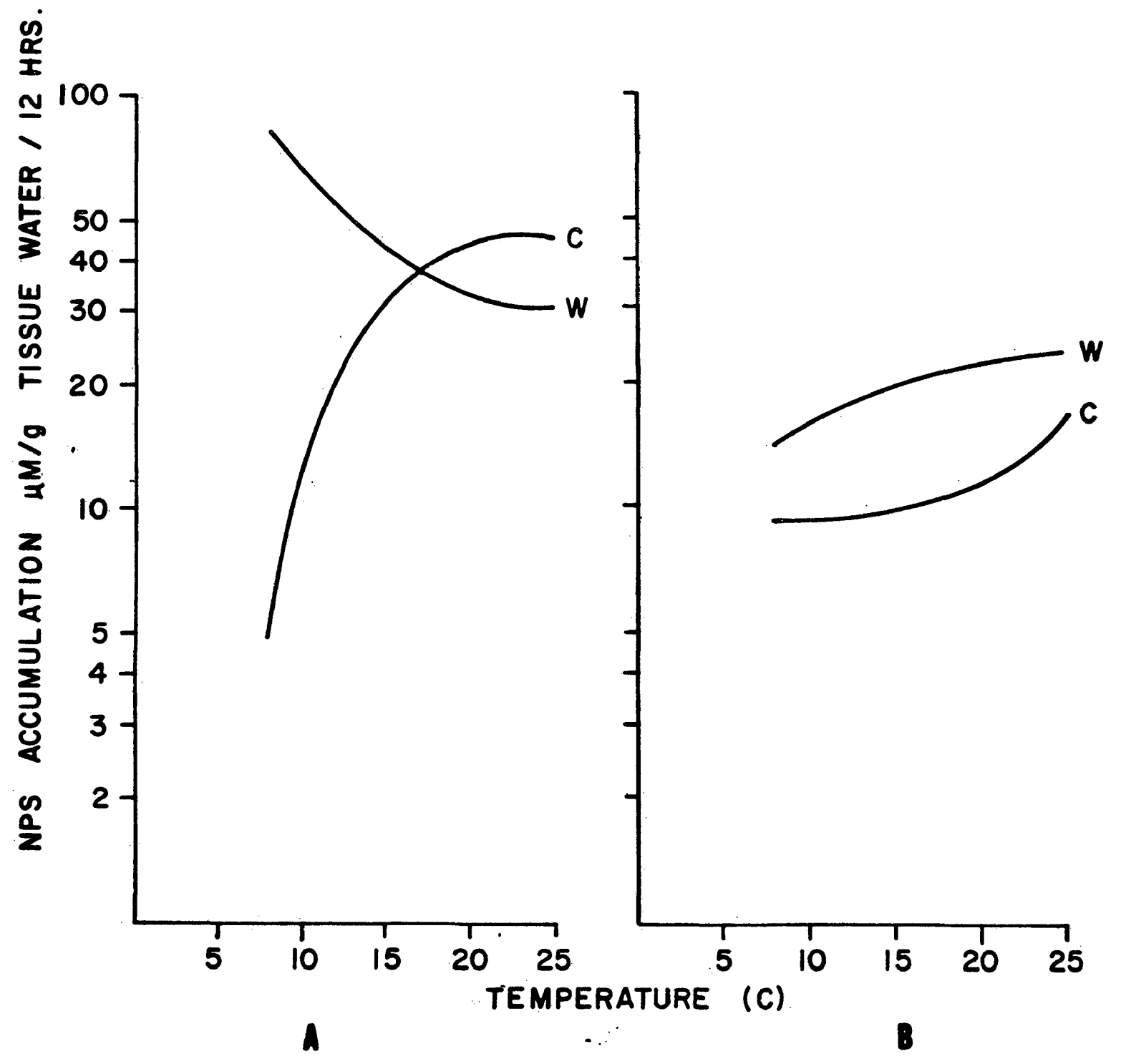


Figure 9. Rate-temperature of NPS accumulation for warm and cold acclimated $\underline{M}$. arenaria over the entire time course of the experiment. 


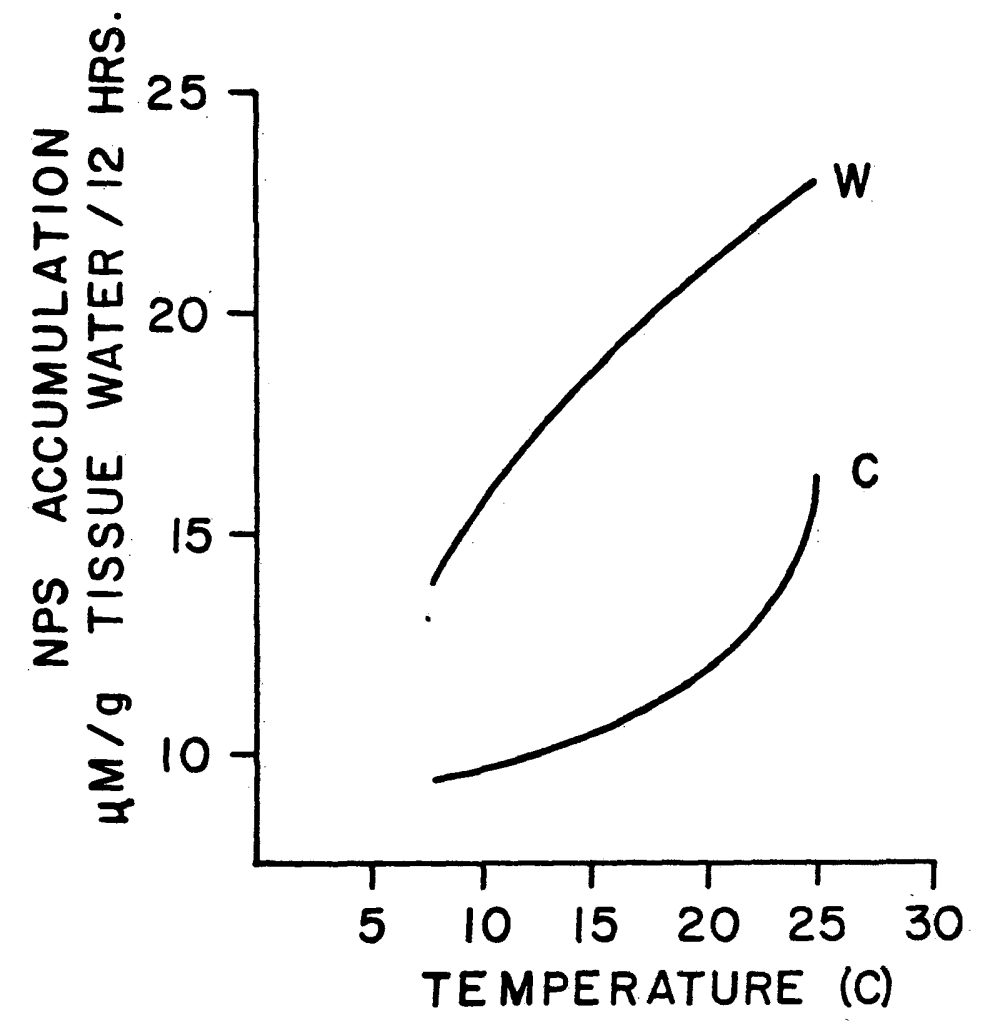




\section{SUMMARY}

1. The accumulation of FAA and NPS in the adductor muscle of $\underline{M}$. arenaria in response to an increased salinity was not linear with time.

2. Three components in the process of NPS and FAA accumulation were proposed: (1) a fast component active during the first 24 hours, (2) a slow component effective from 36 hours and (3) a taurine component effective during the time lag of the fast and slow components.

3. The increase in the alanine concentration accounted for 80 to $90 \%$ of the observed increase in NPS concentration.

4. The high correlation between the decrease in the concentration of aspartic acid and the increase in the concentration of alanine indicates a direct relationship in the formation of alanine from aspartic acid. It is suggested that aspartic acid undergoes a decarboxylation forming alanine.

5. The rate-temperature functions of NPS accumulation for warm and cold

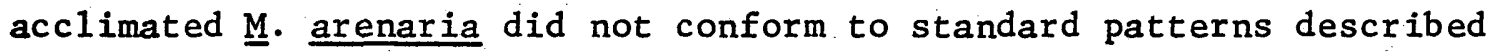
for warm and cold acclimated poikilotherms. 


\section{LITERATURE CITED}

Anders, F., F. Vester, K. Klinke, and H. Schumacher. 1962. Genetische und biochemische Untersuchunger über die Bedeutung der freien Aminosaüren für die tomorgenese bei Art-bzw. Gattungs bastarden 1ibendgebärender Zahnkarpfen (Poeciliidae). Bio1. Zb. 81:45-65.

Awapara, J. 1948. Application of paper chromatography to the estimation of free amino acids in tissue. Arch. Biochem. 19:172-173.

Clark, M. E. 1964. Biochemical studies on the coelomic fluid of Nephtys hombergi (Polychaeta: Nephtyidae), with observations on changes during different physiological states. Biol. Bull. 127:63-84.

Duchateau G., and M. Florkin. 1955. Influence de la température sur 1 'état stationnaire du pool des acides aminés non protéiques des muscles d' Eriocheir sinensis Milne Edwards. Arch. internat. Physiol. Biochem. 63:213-221.

Florkin, M., and E. Schoffeniels. 1965. Euryhalinity and the concept of physiological radiation, p:6-40. In $\mathrm{K}$. A. Munday, [ ed.], Studies in comparative biochemistry. Pergamon Press, New York.

Gilles, R. and E. Schoffeniels. 1966. Décarboxylation des acides aspartique et oxalo acétique chez le homard et l'écrevisse. Bull. Soc. Chem. Biol. 48:397-417.

Hegemann, Von Manfred. 1964. Osmoregulation einiger Krebse, Muscheln und Fische aus dem Greifswalder Bodden. Biol. Zb1. 83:595-602.

Jeuniaux, Ch., S. Bricteux-Gregoire and M. Florkin. 1961. Contribution des acides aminés libres a là régulation osmotique intracellulaire 
chez deux crustacés euryhalins, Leander serratus F. et Leander squilla L. Cahiers Biol. Mar. 2:373-380.

Lange, R. 1963. The osmotic function of amino acids and taurine in the muscle, Mytilus edulis. Comp. Biochem. Physiol. 10:173-179.

Lange, R. 1968. Isosmotic intracellular regulation. Nytt magsin for Zoologi. 16:1-13.

Lynch, M. P., and L. Wood. 1966. Effects of environmental salinity on free amino acids of Crassostrea virginica Gmelin. Comp. Biochem. Physiol. 19:783-790.

Mahler, H., and E. Cordes. 1966. Metabolism of the amino acids, p. 653714. In H. Mahler and E. Cordes, Biological Chemistry, Harper and Row, New York.

Precht, H. 1958. Patterns of temperature adaptation, p. 50-78. In C. L. Prosser [ed.], Physiological adaptation American Physiological Society, Washington.

Prosser, C. L., and F. A. Brown, Jr. 1961. Temperature, p. 238-284. In Comparative animal physiology. W. B. Saunders Co., Philadelphia.

Rao, K. P. 1963. Physiology of low-temperature acclimation in tropical poikilotherms. I. Ionic changes in the blood of the freshwater mussel $\underline{L}$. margenalis and the earthworm Lampito mauritii. Proc. Indian Acad. Sci. Scet. B. 57:290-296.

Saroja, K., and K. P. Rao. 1965. Some aspects of the mechanism of thermal acclimation in the earthworm Lampito mauritii. Z. Vergleich, Physio1. 50:35-54.

Schoffeniels, E. 1960. Origine des acides aminés intervenant dans 1a régulation de la pression osmotique intracellulaire de Eriocheir 
sinensis Milne Edwards. Arch. internat. Physiol. Biochem. 68: 696-698.

Schoffeniels, E. 1964. Cellular aspects of active transport, Vo1. 7, p. 137-202. In M. Florkin and H. S. Mason [ed.], Comparative Biochemistry, Academic Press, New York.

Schoffeniels, E. 1967. Osmoregulation and nitrogen metabolism, p. 157-

182. In E. Schoffeniels, Cellular aspects of membrane permeability, Pergamon Press, New York.

Snedecor, G. 1956. Statistical methods. The Iowa State Univ. Press . $534 \mathrm{p}$. 
VITA

William David DuPaul

Born in Southbridge, Massachusetts, March 23, 1940. Graduated from Mary E. Wells High School, Southbridge, Massachusetts, June 1957. Served on active duty in the U. S. Air Force, July 1957 to September 1960. B. S. Ed. (Biology) State College, Bridgewater, Massachusetts, June 1965. Entered the Virginia Institute of Marine Science of the College of William and Mary, September 1965. Graduate Research Assistant in the Department of Environmental Physiology, September, 1966. 